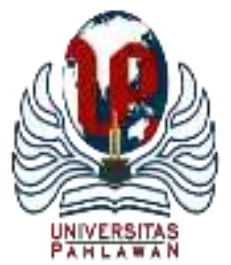

Edukatif : Jurnal Ilmu Pendidikan Volume 4 Nomor 1 Tahun 2022 Halm 851 - 861

EDUKATIF: JURNAL ILMU PENDIDIKAN

Research \& Learning in Education

https://edukatif.org/index.php/edukatif/index

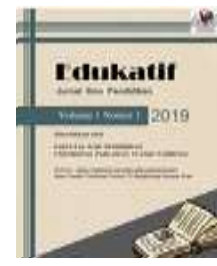

\title{
Analisis Framing Pemberitaan Kasus Pinjaman Online Warga Negara China pada Media Online CNNIndonesia.com dan Nasional Tempo.com
}

\author{
Viona Ainun Rizki As Sidiq ${ }^{1 凶}$, Hendra Setiawan ${ }^{2}$ \\ Universitas Singaperbangsa Karawang, Indonesia ${ }^{1}{ }^{2}$ \\ E-mail : $\underline{\text { 1810631080044@ @student.unsika.ac.id }}{ }^{1}$, hendra.setiawan@ fkip.unsika.ac.id $^{2}$
}

\begin{abstract}
Abstrak
Penelitian ini membahas tentang analisis framing pemberitaan kasus pinjaman onlineyang dilakukan WN China pada media CNNIndonesia.com dan Nasional Tempo.co. Tujuannya guna melihat bagaimana cara media CNNIndonesia.com dan Nasional Tempo.co mengkonstruksi realitas yang terjadi pada kasus pinjol ilegal yang dilakukan WN China. Serta, melihat peristiwa apa saja yang ditonjolkan dan dihilangkan. Hasil penelitianakan disarankan menjadi materi ajar pada teks berita di SMP Kelas VIII yang bertujuan guna membantu siswa dalam memahami materi teks berita di sekolah. Penelitian ini adalah pendekatan kualitatif dengan metode analisis framing model Zhongdang Pan dan Gerald M. Kosicki. Hasil penelitian menunjukkan bahwa pada CNNIndonesia.com dan Nasional Tempo.co mempunyai perbedaan dan persamaan saat melakukan framing berita mengenai kasus pinjol ilegal. Pemberitaan kasus pinjol ini, kedua media mempunyai sudut pandang yang berbeda. CNNIndonesia.com memberitakan tentang kronologi dari awal korban tertarik dengan pinjol ilegal hingga korban bunuh diri akibat mendapatkan pesan ancaman dan berakhir dengan penangkapan tersangka WN China. Sedangkan Nasional Tempo.co memberitakan mengenai pasal-pasal yang menjerat tersangka WN China alias Jon, ancaman hukuman dan denda yang harus dibayar.

Kata Kunci: Berita pinjaman online, media online, analisis framing.
\end{abstract}

\begin{abstract}
This study discusses the analysis of the framing of news on online loan cases by Chinese citizens on CNNIndonesia.com and Tempo.co National media. The aim is to see how the CNNIndonesia.com and National Tempo.co media construct the reality that occurred in the illegal loan-taking case by a Chinese citizen. Also, see what events are highlighted and omitted. The results of the research will be suggested as teaching materials for news texts in SMP Class VIII which aims to assist students in understanding news text material at school. This research is a qualitative approach with the framing analysis method of the Zhongdang Pan and Gerald M. Kosicki models. The results show that CNNIndonesia.com and National Tempo.co have differences and similarities when framing news about cases of illegal borrowing. In reporting on this pinjol case, the two media have different points of view. CNNIndonesia.com reports about the chronology from the beginning of the victim being attracted to illegal loans until the victim committed suicide due to receiving a threatening message and ended with the arrest of a Chinese citizen suspect. Meanwhile, National Tempo.co reported on the articles that ensnared the suspect, a Chinese citizen alias Jon, the threat of punishment and the fine to be paid.
\end{abstract}

Keywords: Online loan news, online media, framing analysis.

Copyright (c) 2022 Viona Ainun Rizki As Sidiq, Hendra Setiawan

$\triangle$ Corresponding author

Email : 1810631080044@student.unsika.ac.id

DOI : https://doi.org/10.31004/edukatif.v4i1.1935

ISSN 2656-8063 (Media Cetak)

ISSN 2656-8071 (Media Online) 
852 Analisis Framing Pemberitaan Kasus Pinjaman Online Warga Negara China pada Media Online

CNNIndonesia.com dan Nasional Tempo.com - Viona Ainun Rizki As Sidiq, Hendra Setiawan

DOI: https://doi.org/10.31004/edukatif.v4i1.1935

\section{PENDAHULUAN}

Pinjaman online (pinjol) berkembang pesat di Indonesia dalam dua tahun terakhir. Hal ini disebabkan karena persyaratan administrasi pinjol relatif lebih mudah dibandingkan dengan pinjaman layanan keuangan formal (Wahyuni \& Turisno, 2019, hal. 380). Kemudahan dan kecepatan yang ditawarkan memunculkan daya tarik tersendiri.Selain itu, situasi ekonomi yang pelik akibat pandemi Covid-19 menjadikan tingginya permintaan pinjam meminjam di masyarakat. Pinjaman online (pinjol) merupakan salah satu fasilitas pinjaman uang oleh badan tertentu dengan memanfaatkan teknologi secara online (Sastradinata, 2020, hal. 297).

Terdapat permasalahan yang krusial terhadap pinjaman online di Indonesia, salah satunya pinjol yang belum mengantongi izin dari Otoritas Jasa Keuangan (OJK) sehingga termasuk kelompok ilegal. Sebab OJK memiliki kewenangan perihal pengaturan terhadap semua hal yang harus dipatuhi perusahaan yang bergerak di bidang pinjaman online (Asti, 2020, hal. 113-114). Jika nantinya terjadi pelanggaran dari peminjam atau pemberi pinjaman, OJK tidak mempunyai hak atas itu (Jumaizah, 2020, hal. 8). Dalam penerapannya terbukti pinjol ilegal kerap melalukan pelanggaran, yaitu membocorkan informasi pribadi nasabah serta menyalahgunakan data dengan melaksanakanaksi ekstrem seperti melaksanakan teror kepada nasabah dalam penagihan pinjaman, Amalina dkk (Disemadi \& Regent, 2021, hal. 608).Kejadian ini diakibatkan lemahnya sistem pengawasan sertapenegakan hukum kepada perusahan yang curang. Dengan maraknya pinjol ilegal, banyak masyarakat yang menjadi korban.

Adanya pinjol ilegal sangat meresahkan masyarakat, permasalahan utama nampak pada data pengaduan Yayasan Lembaga Konsumen Indonesia (YLKI) yang tercatat ada 39,5\% keluhan terhadap metode penagihan yang tidak sama dengan aturan, salah satunya dengan memakai debt collector (Sugangga \& Sentoso, 2020, hal. 48). Dalam menjalani aksinya, biasanyadebt collector melakukan aksi teror yang kejam terhadap peminjam. Teror tersebut bisa menyebabkan gangguan psikologis. Jika ancaman terus dilakukan, maka dapat menyebabkan frustasi hingga percobaan bunuh diri. Dampak lainnya, data diri bisa digunakan untuk hal yang tidak baik, kehilangan pekerjaan, dan denda yang menumpuk.

Baru-baru ini, dampak dari pinjol ilegal dirasakan oleh ibu rumah tangga berinisal WPS (38) di Wonogiri, Jawa Tengah, tewas bunuh diri usai mendapatkan ancaman dan penghinaan terkait pinjaman yang dilakukan. Kini Bareskrim Polri telah menangkap tersangka WN China beserta jaringan sindikat pinjol ilegal yang menyebabkan seorang Ibu tewas bunuh diri. WN China tersebut ditangkap saat hendak terbang ke Turki. Kejadian penangkapan WN China tersebut diliput banyak media, termasuk media online.

Media online merupakan media massa generasi ketiga dalam komunikasi politik yang memungkinkan siapa pun menjadi produsen sekaligus konsumen informasi, Heryanto, 2018 (Rosidin \& Hamid, 2020, hal. 164).Media online sebagai bentuk sederhana pada perkembangan teknologi digital yang mampu mengubah teks, foto, grafik, dan video menjadi informasi digital benbentuk byte (Nurkholifah et al., 2021, hal. 4310). Sedangkan menurut (Romli, 2018, hal. 34) media onlineialah produk jurnalistik online yang didefiniskan sebagai pelapor fakta atau peristiwa yang dibuat serta dibagikan melalui internet. Dalam konteks komunikasi massa, media online merupakan media jurnalistik yang terdapat di internet secara online, terutama di situs berita ataupun portal berita.

Media online merupakansarana komunikasi yang cara penggunaannya dengan memanfaatkan internet (Harnia et al., 2021, hal. 3147).Adapun jenis media onlineialah portal, website (situs web, termasuk blog dan media sosial seperti facebook dan twitter), radio online, tv online, dan surat elektronik. Adapun media online yang menjadi subjek dalam penelitian ialah CNNIndonesia.com dan Nasional Tempo.co.

Media online CNNIndonesia.com ialah salah satu situs berita umum di Indonesia yang diluncurkan pada 20 Oktober 2014. CNNIndonesia.comt elah menjadi media terpopuler dan terpercaya yang menduduki peringkat ke 20 menurut (Alexa.com, 2021).CNNIndonesia.com menayangkan tentang informasi terkini 
seputar politik, sosial, ekonomi, dan lainnya dibelahan dunia (Prabowo, 2018, hal. 4).Tempo.co adalah portal berita dan artikel daring dengan isi berita yang berdasarkan jenis berita, antara lain: nasional, metro, bisnis, olahraga, dan lain sebagainya. Nasional Tempo.co merupakan bagian dari situs berita Tempo.co yang memberitakan peristiwa nasional.

Peneliti mengambil kedua media online tersebut, sebab ditemukan perbedaan dalam pemberitaan yang disajikan sehingga menarik untuk dianalisis. Penelitian ini mengenai pemberitaan kasus pinjaman online ilegal yang dilakukan WN China yang diberitakan di media CNNIndonesia.com dan Nasional Tempo.co. Maka dari itu, analisis ini memiliki tujuan untuk melihat bagaimana cara media CNNIndonesia.com serta Nasional Tempo.co mengkonstruksi realitas yang terjadi pada kasus pinjol illegal yang dilakukan WN China. Serta, melihat peristiwa yang ditonjolkan dan dihilangkan. Namun, untuk mengetahui tujuan dari penelitian ini diperlukan sebuah analisis framing.

Analisis Framing ialah analisis yang digunakan untuk mengetahui bagaimana realitas dibangun oleh media (Fauzi, 2019, hal. 10).Framing dapat menciptakan berita yang secara radikal berbeda apabila wartawan mempunya frame yang berbeda ketika melihat peristiwa tersebut serta menuliskan pandangannnya dalam berita. Secara sederhana, framing digunakan untuk melihat cara pandang wartawan dalam menulis berita. Framing berfokus kepada isu, penonjolan, dan pola penulisan berita.

Analisis framing ialah salah satu metode yang dipakai dalam analisis wacana, khususnya teks media. Analisis framing Zhongdang Pan dan Gerald M. Kociski diimplementasikan dalam penelitian ini.Framing model Pan dan Kosicki merupakan model analisis yang diterapkan guna mengetahui realitas di balik wacana dari media massa yang menghasilkan kesimpulan berbeda apabila analisis dilakukan berbeda, walaupun kasusnya sama(Setyawan, 2018, hal. 102).

Pan dan Kosicki (Rafiq, 2014, hal. 289-290) framing memiliki dua konsepsi. Pertama, konsepsi psikologi menekankan bagaimana seseorang mengolah informasi dalam pribadinya. Kedua, konsepsi sosiologis melihat proses seseorang menguraikan kejadian melalui cara pandang tertentu. Hal ini berkaitan dengan proses pengklasifikasian, pengorganisasian serta penafsiran pengalaman sosialnya dan realitas di luar dirinya.

Perangkat framing memiliki empat struktur, yaitu sintaksis, skrip, tematik dan retoris. Sintaksis ialah proses wartawan memperhatikan susunan umum berita mengenai sebuah kejadian. Sintaksis mengamati dari bagan berita (headline, lead, latar informasi, kutipan, sumber, pernyataan, dan penutup). Skrip berkaitan dengan proses wartawan menggambarkan kejadian ke bentuk berita.Tematik yaitu proses wartawan menuliskan pemikirannya tentang kejadian yang diliput ke dalam proposisi, kalimat ataupun antar kalimat, sehingga membentuk teks berita secara keseluruhan.Retoris berkaitan dengan proses wartawan menekankan makna ke dalam berita. Tematik dapat dilihat dari kata, idiom, grafik sertafoto yang dipakai guna menekankan arti tertentu kepada pembaca, Eriyanto, 2002 (Flora, 2014, hal. 351).

Berdasarkan latar belakang di atas, peneliti memberi judul "Analisis Framing pada Pemberitaan Kasus Pinjaman Online WN China pada Media OnlineCNNIndonesia.com dan Nasional Tempo.co". Hasil penelitian nantinya akan disarankan kepada guru Bahasa Indonesia sebagai materi ajar pada materi teks berita di SMP Kelas VIII. Hal ini dapat dimanfaatkan oleh guru dalam pembelajaran teks berita, terutama dalam menganalisis unsur-unsur yang terdapat dalam teks berita. Oleh karena itu, penelitian ini memiliki tujuan guna membantu siswa dalam memahami materi teks berita di sekolah.

Penelitian mengenai analisis framing model Zhongdang Pan dan Gerald M. Kociski pernah dilakukan oleh, Neng Tika Harnia (Harnia et al., 2021) dengan judul "Analisis Framing Berita Perundungan pada Media Online Detik.Com dan Tribunnews.Com sebagai Bahan Ajar Teks Berita di SMP”. Penelitian ini bertujuan untuk memberikan referensi bahan ajar berupa handout terhadap pembelajaran Bahasa Indonesia materi teks berita pada kelas VIII guna memudahkan siswa dalam memahami materi pembelajaran yang disusun dengan 
menarik dan sederhana. Serta untuk mengetahui bagaimana cara memahami isi suatu pemberitaan pada suatu media yang dikemas sesuai dengan ideologinya sehingga masyrakat tidak termakan oleh berita hoak.

Zahra Febriyanti dan N.R Nadya Karina (Febriyanti \& Karnia, 2021) juga telah melakukan penelitian yang membahas analisis framing model Zhongdang Pan dan Gerald M. Kociski pada media online CNN Indonesia. Penelitian ini berjudul "Konstruksi Berita CNN Indonesia Tentang Gibran Rakabuming Raka Pasca Pilkada Serentak Kotak Solo 2020: Analisis Framing Perspektif Zhongdang Pan - Gerald MKociski”. Tujuan penelitiannya untuk mengetahui analisis framing (bingkai/pengemasan) berita politik portal media online CNN Indonesia mengenai Gibran Rakabuming Raka Pasca Pilkada Serentak Kotak Solo 2020.

Penelitian lainnya pernah dilakukan oleh Siti Mufidah (Mufidah, 2021) dengan judul "Nilai Sosial pada Film Headshot (Analisis Framing: Zhongdang Pan dan Gerald M. Kociski)". Tujuan penelitiannya untuk menjelaskan deskripsi realitas tayangan film Headshot dan menganalisis nilai sosial pada film Headshot dengan teori Framing model Pan \& Kosicki.

Perbedaan penelitian ini dengan penelitian sebelum-sebelumnya, yaitu dalam penelitian peneliti memilih menganalisis framing pemberitaan kasus pinjaman online WN China pada media onlineCNNIndonesia.com dan Nasional Tempo.co. Dengan tujuan untuk melihat bagaimana cara media CNNIndonesia.com serta Nasional Tempo.co mengkonstruksi realitas yang terjadi pada kasus pinjol illegal yang dilakukan WN China.Sertamelihat peristiwa yang ditonjolkan dan dihilangkan. Selain itu, pentingnya penelitian ini untuk disarankan kepada guru Bahasa Indonesia sebagai materi ajar pada materi teks berita di SMP Kelas VIII guna bermanfaat bagi siswa SMP dalam mempelajari definisi teks berita dan cara mengindentifikasi unsur-unsur $5 \mathrm{~W}+1 \mathrm{H}$ dalam berita.

\section{METODE PENELITIAN}

Penelitian ini adalah pendekatan kualitatif yang memiliki tujuan menguraikan realitas yang terjadi dalam berita kasus pinjol ilegal yang dilakukan WN China. Penelitian ini berusaha melihat hal-hal yang sedang terjadi serta mengarahkan kepada temuan yang diperoleh Bungin, 2001 (Anggoro et al., 2018, hal. 236). Sedangkan metode yang diterapkan dalam penelitian, yaitu metode analisis framing model Zhongdang Pan dan Gerald M. Kosicki. Pan dan Kosicki (Anggoro et al., 2018, hal. 236) framing yaitu cara membuat suatu pesan menjadi kianterlihat sehingga khalayak kian tertuju pada pesan tersebut.

Objek penelitian berupa teks berita dari yang berjudul "Buat Ibu di Wonogiri Bunuh Diri, WN China Otak Pinjol Ilegal Ditangkap" dan "Kasus Pinjol Ilegal, Tersangka WNA Terancam Hukuman 20 Tahun Penjara". Sedangkan subjek penelitiannya, yaitu CNNIndonesia.com dan Nasional Tempo.co. Adapun instrumen yang digunakan dalam penelitian, yaitu peneliti sendiri, sebab penelitiannya berbentuk kualitatif di mana informasi diperoleh sendiri oleh peneliti dari dianalisis yang hasilnya berupa penjabaran kata dalam bentuk tulisan.

Teknik pengumpulan data yang diterapkan, ialah teknik menyimak dan catat. Teknik menyimak ini dipakai untuk menyimak penggunaan bahasa pada subjek yang diteliti, Sudaryono (Solihat et al., 2021, hal. 3831).Teknik ini dipakai guna mengetahui kosa kata yang digunakan oleh CNNIndonesia.com dan Nasional Tempo.co. Sedangkan teknik catatini digunakan untuk menuliskan data dengan instrumen penelitian guna mempermudah pengamatan, Sudaryanto (Solihat et al., 2021, hal. 3831).

Teknik analisis data dilakukan dengan cara 1) mengelompokkan berita mengenai kasus pinjol illegal pada CNNIndonesia.com dan Nasional Tempo.co, 2) membaca serta memberi tanda hal-hal penting, 3) menganalisis dengan menerapkan analisis framing model Zhongdang Pan dan Gerald M. Kosicki, 4)menguraikan hasil analisis, dan 5)memberikan kesimpulan. 
855 Analisis Framing Pemberitaan Kasus Pinjaman Online Warga Negara China pada Media Online CNNIndonesia.com dan Nasional Tempo.com - Viona Ainun Rizki As Sidiq, Hendra Setiawan DOI: https://doi.org/10.31004/edukatif.v4i1.1935

\section{HASIL DAN PEMBAHASAN PENELITIAN}

Data yang dipakai dalam penelitian ini, yaitu dua teks berita yang diterbitkan secara online dengan isi topik berita yang sama, yaitu CNNIndonesia.com berjudul "Buat Ibu di Wonogiri Bunuh Diri, WN China Otak Pinjol Ilegal Ditangkap" dan Nasional Tempo.co berjudul "Kasus Pinjol Ilegal, Tersangka WNA Terancam Hukuman 20 Tahun Penjara". Berikut penjabaran data hasil proses analisis dengan model Zhongdang Pan dan Gerald M Kosiski.

\section{Analisis Framing pemberitaan kasus pinjol ilegal pada CNNIndonesia.com Struktur sintaksis}

Tabel 1. Struktur Sintaksis Berita CNNIndonesia.com

\begin{tabular}{ll}
\hline Bagian yang Diamati & \multicolumn{3}{c}{ Penjelasan } \\
\hline Judul & $\begin{array}{l}\text { Pada bagian judul menggambarkan alasan } \\
\text { dari penangkapan WN China yang } \\
\text { merupakan otak dari pinjol ilegal. }\end{array}$ \\
\hline Lead & Bagian lead berita ini berisi tentang informasi \\
& utama mengenai WN China berinisal WJS \\
& alias BH alias JN yang diduga otak pinjol \\
& ilegal yang menyebabkan ibu rumah tanggal \\
& berinisial WPS (38) di Wonogiri, Jawa \\
& Tengah, bunuh diri, ditangkap \\
\hline Latar Informasi & Bagian ini menjelaskan adanya latar belakang \\
& berdasarkan kronologi dari awal korban \\
& tertarik dengan pinjol ilegal hingga korban \\
& bunuh diri akibat mendapatkan pesan \\
& ancaman \\
& Kutipan sumber yang ditulis berdasar pada \\
& narasumber, yaitu Direktur Tindak Pidana \\
& Khusus (Dirtipideksus) Bareskrim Brigjen \\
& Helmy Santika. \\
\hline Kutipan Sumber & Secara keseluruhan, berita ini ditulis \\
& berdasarkan pernyataan yang bersumber dari \\
& Direktur Tindak Pidana Khusus \\
& (Dirtipideksus) Bareskrim Brigjen Helmy \\
& Santika. \\
\hline Pernyataan & Penutup pada berita ini hanya berisi informasi \\
& mengenai jumlah dan inisial tersangka pinjol \\
& ilegal yang telah ditangkap oleh Bareskrim \\
& Polri. \\
\hline Penutup & \\
& \\
&
\end{tabular}

Berdasarkan tabel 1 diatas, diperoleh hasil bahwa struktur sintaksis pada berita tersebut memiliki struktur yang jelas dan sesuai dengan analisis dari Zhongdang Pan dan Gerald M. Kosicki. 
856 Analisis Framing Pemberitaan Kasus Pinjaman Online Warga Negara China pada Media Online CNNIndonesia.com dan Nasional Tempo.com - Viona Ainun Rizki As Sidiq, Hendra Setiawan DOI: https://doi.org/10.31004/edukatif.v4i1.1935

\section{Struktur skrip}

Tabel 2. Struktur Skrip Berita CNNIndonesia.com

\begin{tabular}{ll}
\hline Bagian yang Diamati & \multicolumn{1}{c}{ Penjelasan } \\
\hline What (apa) & $\begin{array}{l}\text { Berita ini menjelaskan peristiwa penangkapan } \\
\text { WN China yang diduga otak pinjol ilegal yang } \\
\text { berawal dari ditemukan korban seorang ibu rumah } \\
\text { tangga tewas bunuh diri. }\end{array}$ \\
\hline Who (Siapa) & $\begin{array}{l}\text { Dalam berita menjelaskan siapa yang menjadi } \\
\text { korban atas kasus pinjol ilegal ini, yaitu seorang } \\
\text { ibu rumah tanggal berinisial WPS (38). }\end{array}$ \\
\hline When (kapan) & $\begin{array}{l}\text { Sejak 27 Oktober Polisi telah melakukan } \\
\text { pemantauan di sekitar kawasan apartemen di } \\
\text { daerah Jakarta Utara. }\end{array}$ \\
\hline Why (mengapa) & $\begin{array}{l}\text { Alasan penangkapan karena tersangka terlibat } \\
\text { dalam kasus pinjol ilegal yang menyebabkan } \\
\text { adanya korban jiwa. }\end{array}$ \\
\hline Where (di mana) & Tersangka otak pinjol ilegal ditangkap di \\
& Terminal 3 Bandara Soekarno Hatta. \\
\hline How (bagaimana) & $\begin{array}{l}\text { Peristiwa penangkapan ini berawal dari seorang } \\
\text { ibu rumah tangga yang tewas bunuh diri akibat } \\
\text { mendapat pesan ancaman dalam penagihan utang } \\
\text { hingga keluarga korban juga ikut mendapat pesan } \\
\text { penghinaan dan pencemaran. }\end{array}$ \\
\hline
\end{tabular}

Berdasarkan tabel 2 di atas, struktur skrip yang menganalisis unsur $5 \mathrm{~W}+1 \mathrm{H}$ dalam media CNNIndonesia.com telah memenuhi dan saling berhubungan.

\section{Struktur tematik}

Tabel 3. Struktur Tematik Berita CNNIndonesia.com

\begin{tabular}{|c|c|}
\hline Bagian yang Diamati & Penjelasan \\
\hline Paragraf, proposisi & $\begin{array}{l}\text { 1. Keseluruhan teks berita kasus tersebut terdiri } \\
\text { atas } 10 \text { paragraf. } \\
\text { 2. Unsur tematik diperkuat dengan kutipan dan } \\
\text { pernyataan dari narasumber yang mendukung } \\
\text { kasus pada teks berita, yaitu Direktur Tindak } \\
\text { Pidana Khusus (Dirtipideksus) Bareskrim } \\
\text { Brigjen Helmy Santika. } \\
\text { 3. Wartawan tidak memakai kata ganti nama untuk } \\
\text { menyebutkan narasumber maupun tersangka. } \\
\text { 4. Bentuk kalimat dalam berita ini, selalu diawali } \\
\text { dengan huruf kapital dan diakhiri dengan tanda } \\
\text { titik. }\end{array}$ \\
\hline
\end{tabular}

Berdasarkan tabel 3 di atas, bagian struktur tematik setiap paragrafnya dicatat dengan baik sehingga antar kalimatnya saling berkaitan.Maka dari itu, dari paragraf satu sampai paragraf 10 pembaca dapat mengerti topik pembahasan dalam isi teks berita. 
857 Analisis Framing Pemberitaan Kasus Pinjaman Online Warga Negara China pada Media Online CNNIndonesia.com dan Nasional Tempo.com - Viona Ainun Rizki As Sidiq, Hendra Setiawan DOI: https://doi.org/10.31004/edukatif.v4i1.1935

\section{Struktur retoris}

Tabel 4. Struktur Retoris Berita CNNIndonesia.com

\begin{tabular}{ll}
\hline Bagian yang Diamati & \multicolumn{1}{c}{ Penjelasan } \\
\hline Kata, idiom, & 1. Frasa" "Tenor waktu" yang digunakan untuk \\
grafik,gambar/foto & menunjukkan waktu atau durasi yang disepakati \\
& untuk melalukan pelunasan pinjaman. \\
& 2. Frasa "payment gateway" yang memiliki arti \\
& teknologi yang digunakan pemilik bisnis dalam \\
& menerima pembayaran dari pelanggan melalui \\
& kartu debit/kredit, dan lain-lain. \\
& 3. Dalam berita ini terdapat gambar ilustrasi \\
& tangan yang sedang diborgol. \\
\hline
\end{tabular}

Berdasarkan tabel 4 di atas, struktur retoris dalam berita yang disampaikan CNNIndonesia.com, lebih banyak menggunakan pernyataan dari sumber. Dalam struktur retoris ini tidak terdapat grafik dan pengandaian. Jadi pada bagian ini, tidak semua bagian ada.

\section{Analisis Framing pemberitaan kasus pinjol ilegal pada Nasional Tempo.co} Struktur sintaksis

Tabel 5. Struktur Sintaksis Berita Nasional Tempo.co

\begin{tabular}{ll}
\hline Bagian yang Diamati & \multicolumn{1}{c}{ Penjelasan } \\
\hline Judul & Judul berita "Kasus Pinjol Ilegal, Tersangka WNA Terancam \\
& Hukuman 20 Tahun Penjara" yang disampaikan oleh Nasional \\
& Tempo.co menggambarkan tersangka WNA kasus pinjol ilegal \\
& yang terancam 20 tahun penjara. \\
\hline Lead & Bagian lead yang disampaikan membahas tentang Direktorat \\
& Tindak Pindana Ekonomi Khusus (Dittipideksus) Bareskrim \\
& Polri menjerat tersangka kasus pinjaman online berinisial WJS \\
& alias Jon dengan pasal berlapis.Jon ialah tersangka yang \\
& berstatus warga negara asing asal Cina. \\
\hline Latar Informasi & Latar informasi yang disampaikan berisi pasal-pasal yang \\
& dikenakan untuk tersangka Jon pada kasus pinjol illegal, serta \\
& hukuman dan denda yang harus dibayarkan tersangka. \\
\hline Kutipan Sumber & Kutipan sumber berasal dari narasumber, yaitu Kasubdit IV \\
& Dittipideksus Bareskrim Kombes Andri Sudarmadi. \\
\hline Pernyataan & Berita ini secara keseluruhan ditulis berdasarkan pernyataan \\
& yang bersumber dari Kasubdit IV Dittipideksus Bareskrim \\
& Kombes Andri Sudarmadi. \\
\hline Penutup & Bagian penutup berisi pernyataan dari Kasubdit IV \\
& Dittipideksus Bareskrim Kombes Andri Sudarmadi mengenai \\
& informasi menangkap tersangka dalam satu jaringan utuh \\
dengan total 13 tersangka yang ditangkap dan dikenakan pasal \\
berlapis.
\end{tabular}

Berdasarkan tabel 5 di atas, struktur sintaksis pada berita tersebut memiliki struktur yang jelas dan sesuai dengan analisis dari Zhongdang Pan dan Gerald M. Kosicki. 
858 Analisis Framing Pemberitaan Kasus Pinjaman Online Warga Negara China pada Media Online CNNIndonesia.com dan Nasional Tempo.com - Viona Ainun Rizki As Sidiq, Hendra Setiawan DOI: https://doi.org/10.31004/edukatif.v4i1.1935

\section{Struktur skrip}

Tabel 6. Struktur Skrip Berita Nasional Tempo.co

\begin{tabular}{ll}
\hline Bagian yang Diamati & \multicolumn{1}{c}{ Penjelasan } \\
\hline What (apa) & $\begin{array}{l}\text { Peristiwa yang terjadi dalam berita ini, yaitu } \\
\text { menjelaskan proses hukum yang menjerat }\end{array}$ \\
& $\begin{array}{l}\text { tersangka kasus pinjol ilegal bernisial WJS } \\
\text { dengan pasal berlapis. }\end{array}$ \\
\hline Who (Siapa) & $\begin{array}{l}\text { Berita tersebut menjelaskan siapa yang menjadi } \\
\text { tersangka dalam kasus ini, yaitu warga negara }\end{array}$ \\
& China bernisial WJS alias Jon \\
\hline When (kapan) & Tersangka Jon ditangkap pada 2 November 2021. \\
\hline Why (mengapa) & penangkapan ini terjadi karena tersangka berperan \\
& sebagai direktur bisnis dan pemilik KSP IMB. \\
\hline Where (di mana) & Tersangka ditangkap di Bandara Soekarno Hatta. \\
\hline How (bagaimana) & $\begin{array}{l}\text { Peristiwa penangkapan tersebut terjadi } \\
\text { berdasarkan hasil pemeriksaan dari sejumlah } \\
\text { tersangka pinjol ilegal yang telah ditangkap lebih } \\
\text { dulu. }\end{array}$ \\
\hline
\end{tabular}

Berdasarkan tabel 6 di atas, skrip $5 \mathrm{~W}+1 \mathrm{H}$ yang terdapat dalam teks berita Nasional Tempo.co secara keseluruhan sudah memenuhi dan saling berkaitan.

\section{Struktur tematik}

Tabel 7. Struktur Tematik Berita Nasional Tempo.co

\begin{tabular}{ll}
\hline Bagian yang Diamati & \multicolumn{1}{c}{ Penjelasan } \\
\hline Paragraf, proposisi & 1. $\begin{array}{l}\text { Berita yang disampaikan Nasional Tempo.co } \\
\text { kasus pinjol ilegal memiliki 5 paragraf. }\end{array}$ \\
2. $\begin{array}{l}\text { Unsur tematik diperkuat dengan kutipan dan } \\
\text { pernyataan dari narasumber yang mendukung } \\
\text { kasus pada teks berita, yaitu Direktorat Tindak }\end{array}$ & $\begin{array}{l}\text { Pindana Ekonomi Khusus (Dittipideksus) } \\
\text { Bareskrim Polri Kombes Andri Sudarmadi. }\end{array}$ \\
3. Pada paragraf 2 wartawan menerapkan kata \\
ganti nama untuk menyebutkan tersangka \\
kasus pinjol. \\
4. Bentuk Kalimat pada berita ini, diawali \\
dengan huruf kapital dan diakhiri dengan \\
tanda titik.
\end{tabular}

Berdasarkan tabel 7 di atas, bagian struktur tematik setiap paragrafnya dicatat dengan baik sehingga antar kalimatnya saling berkaitan. Maka dari itu, dari paragraf satu sampai paragraf 5 pembaca dapat mengerti topik pembahasan dalam isi teks berita. 


\section{Struktur retoris}

Tabel 8. Struktur Retoris Berita Nasional Tempo.co

\begin{tabular}{ll}
\hline Bagian yang Diamati & \multicolumn{1}{c}{ Penjelasan } \\
\hline Kata, idiom, grafik, & 1. \\
gambarasa "foto & orang yang berperan penting dalam suatu \\
& kejadian. \\
2. & Dalam berita ini ada sebuah foto yang \\
& menampilkan Kabagpenum Kombes Ahmad \\
& Ramadhan bersama Direktur Direktorat Tindak \\
& Pindana Ekonomi Khusus (Dir Dittipideksus) \\
& Brigjen Pol Helmy Santika saat memberikan \\
& keterangan pers terkait pengungkapan jaringan \\
& sindikat pinjaman online ilegal di Bareskrim \\
& Polri, Jakarta. \\
\hline
\end{tabular}

Berdasarkan tabel 8 di atas, struktur retoris dalam berita yang disampaikan Nasional Tempo.co, lebih banyak menggunakan pernyataan dari sumber. Dalam struktur retoris ini tidak terdapat bagian grafik dan pengandaian. Jadi pada bagian ini, tidak semua bagian ada.

Berdasarkan hasil analisis framing Zhongdang Pan dan Gerald M. Kosicki yang disajikan pada tabel di atas, analisis framing pada kedua berita tersebut mempunyai perbedaan dan persamaan. Perbedaannya terlihat dari gambar yang ditampilkan. Pada CNNIndonesia.comhanya menampilkan gambar ilustrasi. Sedangkan Nasional Tempo.co menampilkan gambar saat memberikan keterangan pers terkait penangkapan tersangka kasus pinjol ilegal. Pada struktur skrip, CNNIndonesia.com tidak menjelaskan secara detail tanggal penangkapan tersangka. Sedangkan Nasional Tempo.co menuliskannya dengan jelas kapan tersangka tersebut ditangkap. Dalam hasil analisis ini juga terdapat persamaan, yaitu pada struktur retoris keduanya sama-sama tidak memiliki unsur grafik dalam berita.

Hasil penelitian ini sejalan dengan beberapa penelitian yang telah dilakukan. Penelitian analisis framing Zhongdang Pan \& Gerald M. Kosicki dalam pemberitaan kasus pinjol ilegal pada CNNIndonesia.com dan Nasional Tempo.co juga bermanfaat bagi siswa SMP dalam mempelajari definisi teks berita dan cara mengindentifikasi unsur-unsur $5 \mathrm{~W}+1 \mathrm{H}$ dalam berita. Sebab dalam metode analisis framing terdapat struktur skrip yang menganalisis unsur-unsur teks berita, yaitu $5 \mathrm{~W}+1 \mathrm{H}$. Maka dari itu, hasil penelitian ini bermanfaat bagi siswa SMP kelas VIII dalam menganalisis teks berita.

\section{KESIMPULAN}

Berdasarkan hasil penelitian, maka disimpulkan bahwa CNNIndonesia.com dan Nasional Tempo.co mempunyai perbedaan dan persamaan saat melakukan framing terhadap pemberitaankasus pinjol ilegal. Pemberitaan kasus pinjol ini, kedua media mempunyai sudut pandang yang berbeda. CNNIndonesia.com memberitakan tentang kronologi dari awal korban tertarik dengan pinjol ilegal hingga korban bunuh diri akibat mendapatkan pesan ancaman dan berakhir dengan penangkapan tersangka WN China. Sedangkan Nasional Tempo.co memberitakan mengenai pasal-pasal yang menjerat tersangka WN China alias Jon, ancaman hukuman dan denda yang harus dibayar. Penulisan berita pada kedua media ini sudah memakaiunsur $5 \mathrm{~W}+1 \mathrm{H}$ dengan baik. Pada media CNNIndonesia.com, wartawan tidak menggunakan kata ganti nama serta sumber berita berasal dari Brigjen Helmy Santika. Sementara pada media Nasional Tempo.co, wartawan menggunakan kata ganti nama dan sumber berita berasal dari Kombes Andri Sudarmadi. Secara keseluruhan 
kedua media ini memakai kata-kata sederhana yang mudah dimengerti oleh masyarakat walaupun masih ada beberapa kata asing dalam penulisan berita di kedua media tersebut.

Hasil penelitian ini akan disarankan kepada Guru Bahasa Indonesia SMP kelas VIII sebagai materi ajar dalam materi teks berita. Hal ini dapat dimanfaatkan oleh guru dalam pembelajaran teks berita, terutama dalam menganalisis unsur-unsur yang terdapat teks berita. Sebab dalam metode analisis framing terdapat struktur skrip yang menganalisis unsur-unsur teks berita, yaitu $5 \mathrm{~W}+1 \mathrm{H}$. Selain itu, diharapkan dapat membantu siswa dalam memahami materi teks berita.

\section{DAFTAR PUSTAKA}

Alexa.Com. (2021). Top Sites In Indonesia. Alexa.Com. Https://Www.Alexa.Com/Topsites/Countries/Id. Diakses 22 November 2021.

Anggoro, A. D., Purwati, E., \& Hilman, Y. A. (2018). Donald Trump Dan Berita Imigran Di Aljazeera.Com Dan Foxnews.Com. Jurnal Ilmu Komunikasi, 15(2), 233-246. Https://Doi.Org/10.24002/Jik.V15i2.1201

Asti, N. P. M. D. P. (2020). Upaya Hukum Otoritas Jasa Keuangan (Ojk) Dalam Mengatasi Layanan Pinjaman Online Ilegal. Acta Comitas, 5(1), 111-122. Https://Doi.Org/10.24843/Ac.2020.V05.I01.P10

Disemadi, H. S., \& Regent. (2021). Urgensi Suatu Regulasi Yang Komprehensif Tentang Fintech Berbasis Pinjaman Online Sebagai Upaya Perlindungan Konsumen Di Indonesia. Jurnal Komunikasi Hukum, 7(2), 605-618. Https://Ejournal.Undiksha.Ac.Id/Index.Php/Jkh

Fauzi, H. (2019). Analisis Framing Model Pan Dan Kosicki Berita Kampanye Pemilihan Presiden Dan Wakil Presiden Indonesia 2019 Pada Media Cetak Harian Duta Masyarakat Rentang Waktu 23 September 30 November 2019. Universitas Negeri Sunan Ampel Surabaya.

Febriyanti, Z., \& Karnia, N. R. N. (2021). Konstruksi Berita Cnn Indonesia Tentang Gibran Rakabuming Raka Pasca Pilkada Serentak Kota Solo 2020 : Analisis Framing Perspektif Zhongdang Pan - Gerald M Kosicki. Intelektiva : Jurnal Ekonomi, Sosial \& Humaniora, 2(06), 146-155.

Flora, E. (2014). Analisis Framing Berita Calon Presiden Ri 2014-2019 Pada Surat Kabar Kaltim Post Dan Tribun Kaltim. Ejournal Ilmu Komunikasi, 2(3), 347-356.

Harnia, N. T., Meliasanti, F., \& Setiawan, H. (2021). Analisis Framing Berita Perundungan Pada Media Online Detik.Com Dan Tribunnews.Com Sebagai Bahan Ajar Teks Berita Di Smp. Edukatif: Jurnal Ilmu Pendidikan, 3(5), 3145-3153. Https://Doi.Org/Https://Doi.Org/10.31004/Edukatif.V3i5.1240

Jumaizah. (2020). Alasan Penggunaan Pinjaman Online Ilegal Beserta Dampaknya (Studi Kasus Masyarakat Kelurahan Jemur Wonosari) [Universitas Islam Negeri Sunan Ampel Surabaya]. Http://Www.Akrabjuara.Com/Index.Php/Akrabjuara/Article/View/919

Mufidah, S. (2021). Nilai Sosial Film Headshot (Analisis Framing: Zhongdang Pan \& Gerald M. Kosicki). Institut Agama Islam Negeri Ponorogo.

Nurkholifah, A., Supriadi, O., \& Mujtaba, S. (2021). Analisis Kohesi Dan Koherensi Pada Isu Nasional Di Media Online Kompas.Com Dan Jawapos.Com Edisi April 2021. Edukatif: Jurnal Ilmu Pendidikan, 3(6), 4309-4319. Https://Doi.Org/Https://Doi.Org/10.31004/Edukatif.V3i6.1279

Prabowo, H. (2018). Analisis Framing Kasus Lgbt Pada Media Online Cnn Indonesia Dan Hidayatullah.Com Tahun 2016 [Universitas Islam Indonesia Yogyakarta]. Https://Doi.Org/10.1103/Physrevb.101.089902\%0ahttp://Dx.Doi.Org/10.1016/J.Nantod.2015.04.009\% 0ahttp://Dx.Doi.Org/10.1038/S41467-018-05514-9\%0ahttp://Dx.Doi.Org/10.1038/S41467-019-138561\%0ahttp://Dx.Doi.Org/10.1038/S41467-020-14365-2\%0ahttp://Dx.Doi.Org/1

Rafiq, F. (2014). Pembingkaian Berita Bencana Alam Di Harian Fajar Edisi Bulan Januari-Februari 2014 (Analisis Framing) [Uin Alauddin Makassar]. Http://Repositori.Uin-Alauddin.Ac.Id/10840/ 
861 Analisis Framing Pemberitaan Kasus Pinjaman Online Warga Negara China pada Media Online CNNIndonesia.com dan Nasional Tempo.com - Viona Ainun Rizki As Sidiq, Hendra Setiawan DOI: https://doi.org/10.31004/edukatif.v4i1.1935

Romli, A. S. M. (2018). Jurnalistik Online: Panduan Mengelola Media Online (I. Kurniawan \& M. A. Elwa (Ed.)). Nuansa Cendekia: Bandung.

Rosidin, A. B., \& Hamid, A. (2020). Media Online Dan Kerja Digital Public Relations Politik Pemerintah Dki Jakarta. Wacana: Jurnal Ilmiah Ilmu Komunikasi, 19(2), 164-174. Https://Doi.Org/10.32509/.V19i2.1046

Sastradinata, D. N. (2020). Aspek Hukum Lembaga Pinjaman Online Ilegal Di Indonesia. Jurnal Independent Fakultas Hukum, 8(1), 293-301. Https://Doi.Org/10.30736/Ji.V8i1.115

Setyawan, A. (2018). Analisa Framing Aksi Solidaritas Bela Rohingya Dalam Detik.Com Dan Republika $\begin{array}{llr}\text { Online. Jurnal } & \text { Komunikasi, } & \text { 100-108. }\end{array}$ Http://Ejournal.Bsi.Ac.Id/Ejurnal/Index.Php/Jkom/Article/View/3736

Solihat, M., Setiawan, H., \& Meliasanti, F. (2021). Kajian Morfologis Pada Pemberitaan Habib Rizieq Shihab Rekomendasinya Sebagai Materi Menyusun Teks Berita Di Smp. Edukatif: Jurnal Ilmu Pendidikan, 3(6), 3828-3838. Https://Doi.Org/Https://Doi.Org/10.31004/Edukatif.V3i6.1259

Sugangga, R., \& Sentoso, E. H. (2020). Perlindungan Hukum Terhadap Pengguna Pinjaman Online (Pinjol) Ilegal. Pajoul (Pakuan Justice Journal Of Law), 01(01), 47-61. Https://Journal.Unpak.Ac.Id/Index.Php/Pajoul/Index

Wahyuni, R. A. E., \& Turisno, B. E. (2019). Praktik Finansial Teknologi Ilegal Dalam Bentuk Pinjaman Online Ditinjau Dari Etika Bisnis. Jurnal Pembangunan Hukum Indonesia, 1(3), 379-391. Https://Doi.Org/10.14710/Jphi.V1i3.379-391 